\title{
Biologic aspects of different species of Pachodynerus (Hymenoptera; Vespidae; Eumeninae)
}

\author{
Buschini, MLT.* and Buss, CE. \\ Departamento de Biologia, Universidade Estadual do Centro-Oeste - UNICENTRO, \\ Rua Presidente Zacarias, 875, CEP 85010-990, Guarapuava, PR, Brazil \\ *e-mail: isatunes@yahoo.com.br \\ Received April 24, 2009 - Accepted August 31, 2009 - Distributed August 31, 2010
}

(With 2 figures)

\begin{abstract}
The aim of this study was to compare biological aspects of the Pachodynerus species occurring in the Parque Municipal das Araucárias, Guarapuava, Paraná, Southern Brazil. It was carried from December 2001 to December 2004. Forty one nests belonging to 5 species were collected, of which 17 Pachodynerus guadulpensis, 15 Pachodynerus sp., 1 Pachodynerus argentinus, 1 Pachodynerus ca guadulpensis and 7 Pachodynerus nasidens. The nesting activity of Pachodynerus sp., P. argentinus and P. guadulpensis occurred in similar periods, from December to March, with the exception of P.guadulpensis, that built one nest in October. Pachodynerus ca guadulpensis nested in March and P. nasidens from January to April. The nests of Pachodynerus species present a very similar architecture, comprising a linear series of cylindrical cells that fit perfectly into each other forming a continuous tube. With these results we were able to conclude that, even though Pachodynerus species present common characteristics, such as nest architecture, nesting activities and habitats in which they occur, the used resources, mortality rates, etc., vary among groups of species occurring in different regions.
\end{abstract}

Keywords: nesting biology, Eumeninae, Pachodynerus, trap-nests.

\section{Aspectos biológicos de diferentes espécies de Pachodynerus (Hymenoptera; Vespidae; Eumeninae)}

\section{Resumo}

O objetivo deste trabalho foi comparar aspectos biológicos das espécies de Pachodynerus que ocorrem no Parque Municipal das Araucárias, Guarapuava, Paraná, Sul do Brasil. Ele foi realizado de dezembro de 2001 a dezembro de 2004. Quarenta e um ninhos de cinco espécies foram coletados sendo 17 de Pachodynerus guadulpensis, 15 de Pachodynerus sp., um de Pachodynerus argentinus, um de Pachodynerus ca guadulpensis e sete de Pachodynerus nasidens. As nidificações de Pachodynerus sp., P. argentinus e P. guadulpensis ocorreram de dezembro a março, com exceção de $P$. guadulpensis, que construiu um ninho em outubro. Pachodynerus ca guadulpensis nidificou em março e P. nasidens de janeiro a abril. Os ninhos de todas as espécies de Pachodynerus apresentaram arquitetura similar, com uma série linear de células cilíndricas que se encaixam perfeitamente umas nas outras, formando um tubo contínuo. Pelos resultados deste estudo nós concluímos que, mesmo apresentando características em comum, como a arquitetura dos ninhos, atividades de nidificação e habitats onde ocorrem, os recursos usados pelas espécies de Pachodynerus bem como as suas taxas de mortalidades, etc., variam entre grupos de espécies que ocorrem em diferentes regiões.

Palavras-chave: biologia de nidificação, Eumeninae, Pachodynerus, ninhos-armadilha.

\section{Introduction}

The family Vespidae comprises approximately 4,600 species divided into six current monophyletic subfamilies (Carpenter, 1981) and one extinct (Carpenter and Rasnitsyn, 1990).

The subfamily Eumeninae is the largest among Vespidae, including over 3,000 described species and approximately 260 genus (Carpenter and Marques, 2001; Carpenter and Garcet-Barrett, 2002). Most species of Eumeninae are

predatory, solitary wasps, but some show social behaviour (Carpenter and Garcet-Barrett, 2002).

The genus Pachodynerus Saussure is amply distributed throughout the American continent occurring in the entire Neotropical region (Freeman and Jayasingh, 1975a, 1975b) with approximately 45 described species (Willink and Roig-Alsina, 1998). Species of this genus measure between 7 to $14 \mathrm{~mm}$ and have black integument with 
yellow stains. They are solitary and have a great nesting behaviour plasticity (Willink and Roig-Alsina, 1998) since there is species of this genus that nest on abandoned insect burrows and others excavate nests in the soil or construct nests attached to plants or rocks using mud and water (Cowan, 1991). Their nests are composed of linear series of cells provisioned with previously paralysed lepidopteran larvae (Assis and Camillo, 1997) and the wasp's eggs are attached to the upper face of the cell by a thin and short peduncle (Jayasingh, 1980).

Since this genus is poorly known and studied especially in Brazil, the aim of this study was to compare biological aspects of Pachodynerus species in a subtropical region in Brazil.

\section{Material and Methods}

\subsection{Study area}

This study was carried out in the Parque Municipal das Araucárias, in the municipality of Guarapuava, State of Paraná, Southern Brazil $\left(25^{\circ} 23^{\prime} \mathrm{S}\right.$ and $51^{\circ} 27^{\prime} \mathrm{W}$, $1,120 \mathrm{~m}$ of altitude). This area is characterised by a wet, cool season, and during the warmest months the average temperature is less than $22{ }^{\circ} \mathrm{C}$. Hoar frosts are common and severe.

Collections were carried out from December 2001 to December 2004 and were concentrated in a very heterogeneous site, with Araucaria forests, swamps and grasslands. The grasslands are characterised, physionomically, by areas of low grasses and no bushes. Species belonging to Cyperaceae, Leguminosae, Verbenaceae, Compositae and Umbelliferae are the main ones found in this habitat. Surrounded by the grasslands is the Araucaria forest, where there is a predominance of Araucaria angustifolia (Bertolini). (Coniferae Araucariaceae). The swamps are located in the lowest regions of the park composed mainly by grasses and Compositae.

\subsection{Sampling program}

Nests of Pachodynerus were obtained using trap-nests made of $25 \times 20 \times 120 \mathrm{~mm}$ wooden boxes (Araucaria angustifolia), drilled longitudinally to a depth of $80 \mathrm{~mm}$ with 7.0, 10.0, and $13.0 \mathrm{~mm}$ aperture diameters. Before being drilled, the wooden blocks were sawed in half longitudinally and then held together with adhesive tape to allow the examination of the cavities when opened.

For each habitat, two areas were studied, with 2 transects per area and 4 sampling stations per transect. Twelve trap-nests were placed at each sampling station, four of each opening diameter, totaling 576 traps. Each trap was placed at $1.5 \mathrm{~m}$ above the ground and inspected every two weeks. At each inspection, all completed Pachodynerus nests were removed and immediately replaced with empty traps of the same diameter. The nests were then brought to the laboratory in order to investigate their contents. If eggs and/or larvae were present, the nest was closed to allow the completion of the life-cycle and the emergence of the adults. Recently emerged adults were carefully removed and weighed.
The cell volume was calculated using the cylinder formula and the sex ratio using the ratio between the numbers of females and males.

\section{Results}

A total of 41 nests belonging to 5 species was collected, of which 17 were Pachodynerus guadulpensis Saussure, 15 Pachodynerus sp., 1 Pachodynerus argentinus Saussure, 1 Pachodynerus ca guadulpensis Saussure and 7 Pachodynerus nasidens Latreille.

\subsection{Seasonality and nesting activity in different habitats}

The nests of Pachodynerus sp. and P. argentinus were all founded in grassland areas. Pachodynerus guadulpensis also built most of their nests in grassland areas, although there were some built in Araucaria Forest. The nesting activity of these 3 species occurred from December to March, with the exception of P.guadulpensis, that built one nest in October. Pachodynerus ca guadulpensis founded only one nest in swamp areas, nesting dur ing the month of March. Pachodynerus nasidens, on the other hand, nested in both grassland and swamp areas, from December to April (Figure 1).

\subsection{Nest architecture}

They showed a very similar architecture, comprising a linear series of cylindrical cells that fit perfectly into each other forming a continuous tube. The cell partitions are made of mud, thick at the extremities and thinner at the middle. Some nests showed a mud coating at the bottom and lateral walls. The closure plug was made of a thick layer of mud. All species founded their nests only in $0.7 \mathrm{~cm}$ diameter traps (Figure 2 and Table 1).

Pachodynerus guadulpensis nests showed a thin layer of mud at the bottom, and most of them did not present any mud on the lateral walls. The mud colour pattern varied from dark brown to reddish brown. Intercalary cells occurred in 3 nests.

The nests of Pachodynerus sp. showed a greater number of cells than those of other species, due to the fact that the

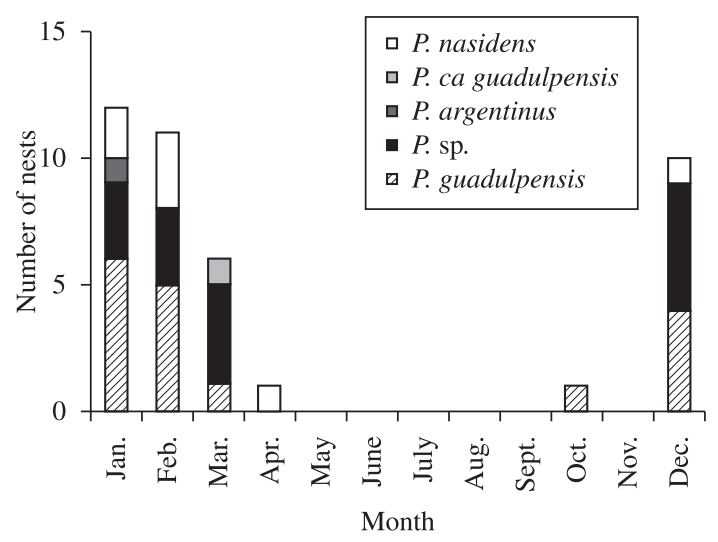

Figure 1. Number of nests established for different species of Pachodynerus in Parque Municipal das Araucárias, Guarapuava (PR), from December 2001 to December 2004. 
cells are smaller and rounder. They presented mud coating at the bottom and lateral walls. The mud coloration ranged from opaque to reddish or dark brown. Most of them presented vestibular cells and intercalar cells occurred in
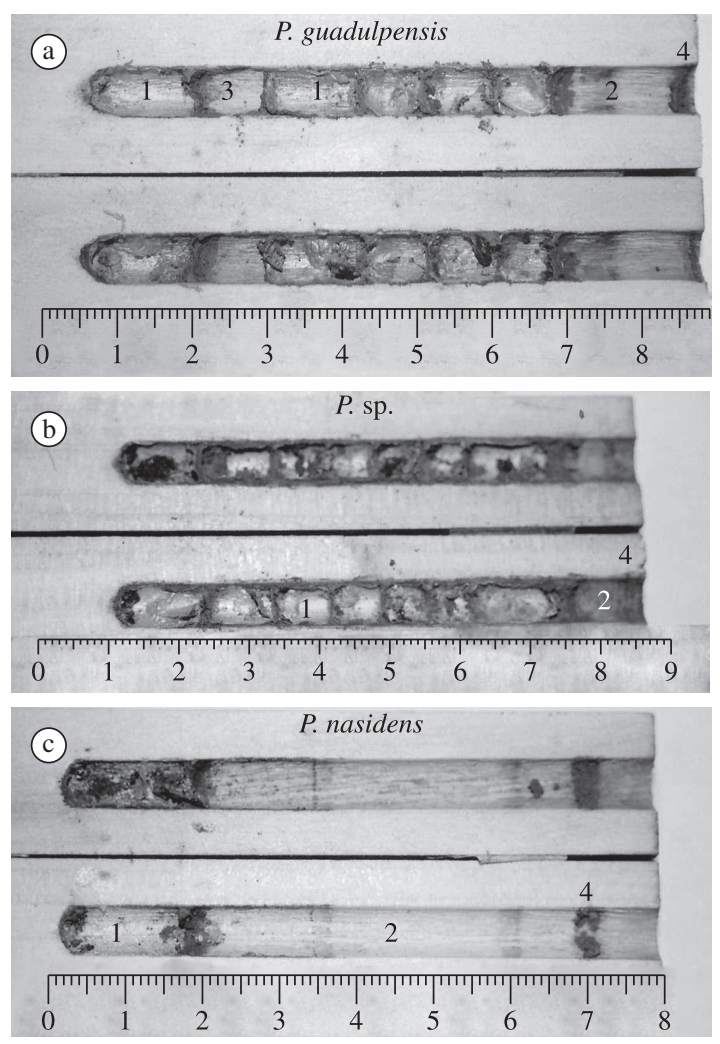

Figure 2. Nests of different species of Pachodynerus established in trap-nest with linear cells: a) Pachodynerus guadulpensis, b) Pachodynerus sp., c) Pachodynerus nasidens, (1) Provisioned cell, (2) Vestibular cell, (3) Intercalary cell, (4) Closure plug. only one nest. The average volume of female cells was slightly higher than that of male cells (Table 2).

As mentioned before, only one nest of $P$. argentinus and of $P$. ca guadulpensis was collected. The Pachodynerus argentinus nest presented 6 cells, the first vestibular. The cell partitions were thin and made out of dark brown mud. The nests of $P$. ca guadulpensis also contained only one vestibular cell but the closing plug was triple. Neither bottom nor lateral walls were coated with mud.

The nest architecture of $P$. nasidens is slightly different from that of the other species because their nests have few provisioned cells and a very long vestibular cell, occupying almost all of the length of the trap-nest. Most nests showed a discreet amount of mud coating the bottom and lateral walls varying from dark to opaque brown mud. Most of them presented vestibular cells, which occurred in six out of the seven found nests. Only one nest presented intercalary cells.

\subsection{Cocoon structure}

No apparent morphological difference was observed between cocoons of different species. All presented a silvery colouration and were adhered to the cells walls, occupying all their extension.

\subsection{Development period, emergence and sex ratio}

\subsubsection{Pachodynerus guadulpensis}

Twelve females and sixteen males emerged, resulting in a sex ratio of 1.3 males for each female. Females presented an average weight of $0.039 \mathrm{~g}$ and males $0.032 \mathrm{~g}$. In a nest from which only females emerged, the wasps entered diapause during winter, with a development period of 295 days. The juveniles of all other nests did not enter diapauses and presented an average development period of 32 days for females and 29 days for males. This species is multivoltine with 6 generations throughout the year, spending winter in diapause in the adult stage.

Table 1. Structure of nests of Pachodynerus species in trap-nests of $0.7 \mathrm{~cm}$ diameter. Values are means \pm standard deviations, with sample sizes indicated.

\begin{tabular}{cccccc}
\hline & $\begin{array}{c}\text { Pachodynerus } \\
\text { guadulpensis }\end{array}$ & $\begin{array}{c}\text { Pachodynerus } \\
\text { sp. }\end{array}$ & $\begin{array}{c}\text { Pachodynerus } \\
\text { argentinus }\end{array}$ & $\begin{array}{c}\text { Pachodynerus ca } \\
\text { guadulpensis }\end{array}$ & $\begin{array}{c}\text { Pachodynerus } \\
\text { nasidens }\end{array}$ \\
\hline Total nest & $7.88 \pm 0.52$ & $7.75 \pm 0.88$ & $8.04 * *$ & $8.01 * *$ & $7.72 \pm 0.39$ \\
length $(\mathrm{cm})$ & $\mathrm{n}=15$ & $\mathrm{n}=13$ & & $\mathrm{n}=6$ \\
Number of & $1.18 \pm 0.39$ & $1.18 \pm 0.41$ & $1 * *$ & $1 * *$ & $1.67 \pm 0.82$ \\
vestibulary cells & $\mathrm{n}=17$ & $\mathrm{n}=11$ & & $\mathrm{n}=6$ \\
Number of & $3.52 \pm 1.69$ & $5.50 \pm 1.75$ & $5 * *$ & $4 * *$ & $2.75 \pm 2.05$ \\
provisioned cells & $\mathrm{n}=21$ & $\mathrm{n}=16$ & & & $\mathrm{n}=8$ \\
Number of cells & $1.00 \pm 0.00$ & 1 & $*$ & & 1 \\
intercalar & $\mathrm{n}=3$ & $0.21 \pm 0.08$ & $0.15 \pm 0.04$ & $0.18 \pm 0.014$ & $0.24 \pm 0.13$ \\
Thickness of cell & $0.23 \pm 0.13$ & $\mathrm{n}=63$ & $\mathrm{n}=5$ & $\mathrm{n}=4$ & $\mathrm{n}=24$ \\
partition $(\mathrm{cm})$ & $\mathrm{n}=64$ & $0.62 \pm 0.38$ & $0.21^{* *}$ & $0.66^{* *}$ & $0.38 \pm 0.11$ \\
Thickness of & $0.54 \pm 0.29$ & $\mathrm{n}=13$ & & & $\mathrm{n}=7$ \\
closing plug $(\mathrm{cm})$ & $\mathrm{n}=15$ & $0.17 \pm 0.06$ & $*$ & $*$ & $0.18 \pm 0.09$ \\
Thickness of & $0.23 \pm 0.15$ & $\mathrm{n}=6$ & & & $\mathrm{n}=2$ \\
bottom nest $(\mathrm{cm})$ & $\mathrm{n}=9$ & & & & \\
\hline
\end{tabular}

*Data not available; $* *$ only one observation was available. 
Table 2. Weights of males and females of Pachodynerus species and volume of their respective cells. Values are means \pm standard deviations, with sample sizes indicated.

\begin{tabular}{cccccc}
\hline & $\begin{array}{c}\text { Pachodyrerus } \\
\text { guadulpensis }\end{array}$ & $\begin{array}{c}\text { Pachodyrerus } \\
\text { sp. }\end{array}$ & $\begin{array}{c}\text { Pachodyrerus } \\
\text { argentinus }\end{array}$ & $\begin{array}{c}\text { Pachodynerus ca } \\
\text { guadulpensis }\end{array}$ & $\begin{array}{c}\text { Pachodyrerus } \\
\text { nasidens }\end{array}$ \\
\hline Weight of & $0.032 \pm 10.76$ & $0.029 \pm 6.57$ & $0.020 \pm 4.00$ & $0.030 \pm 0.0$ & $0.035 \pm 20.34$ \\
Male (g) & $\mathrm{n}=16$ & $\mathrm{n}=13$ & $\mathrm{n}=2$ & $\mathrm{n}=2$ & $\mathrm{n}=5$ \\
Weight of & $0.039 \pm 13.70$ & $0.044 \pm 11.29$ & 0.023 & $0.047 \pm 1.41$ & $0.025 \pm 19.23$ \\
females $(\mathrm{g})$ & $\mathrm{n}=12$ & $\mathrm{n}=24$ & & $\mathrm{n}=2$ & $\mathrm{n}=2$ \\
Male cell & $0.42 \pm 0.20$ & $0.27 \pm 0.04$ & $*$ & $*$ & $*$ \\
volume $\left(\mathrm{cm}^{3}\right)$ & $\mathrm{n}=13$ & $\mathrm{n}=6$ & $*$ & & $*$ \\
Female cell & $0.45 \pm 0.08$ & $0.36 \pm 0.12$ & $*$ & & \\
volume $\left(\mathrm{cm}^{3}\right)$ & $\mathrm{n}=6$ & $\mathrm{n}=15$ & & & \\
\hline
\end{tabular}

*Data not available; $* *$ only one observation was available.

\subsubsection{Pachodynerus sp.}

Twenty three females and 13 males emerged, resulting in a sex ratio of 1.8 females for each male. Females presented an average weight of $0.044 \mathrm{~g}$ and males $0.029 \mathrm{~g}$ (Table 2).

No specimen entered diapause during winter in the juvenile stage. The average development period was 36 days for females and 31 days for males. This species is also multivoltine, with four generations throughout the year, diapausing during winter in the adult stage.

\subsubsection{Pachodynerus argentinus}

Two males and one female emerged, resulting in a sex ratio of 1.5 males for each female. Males presented an average weight of $0.020 \mathrm{~g}$ and the only female that emerged weighed $0.023 \mathrm{~g}$ (Table 2).

No specimen entered diapauses during winter while in the juvenile stage. The average development period for both males and females was 50 days (Table 2). Either this species presents only one generation throughout the year, entering diapauses during winter, or it is a multivoltine species. However, since it is rare, we were not able to collect a greater number of nests in other months.

\subsubsection{Pachodynerus ca guadulpensis}

Two females and two males emerged, totalling a sex ratio of one female for every male. The females presented an average weight of $0.047 \mathrm{~g}$ and males $0.030 \mathrm{~g}$ (Table 2).

No specimen entered diapause during the juvenile stage. As is the case for $P$. argentinus, this species might be univoltine, occurring only in January, or multivoltine, but having not being captured in other months because it is rare and thus less abundant.

\subsubsection{Pachodynerus nasidens}

Three females and six males emerged, resulting in a sex ratio of two males for each female. The average weight was $0.025 \mathrm{~g}$ for females and $0.035 \mathrm{~g}$ for males (Table 2).

No specimen entered diapause during the juvenile stage and the average development period was 27 days for females and 36 days for males. This species is multivoltine with four generations throughout the year and diapausing during winter in the adult stage.

\subsection{Mortality and natural enemies}

\subsubsection{Pachodynerus guadulpensis}

Mortality in $37(40.30 \%)$ of the 67 provisioned cells was observed. Five of these $(6.75 \%)$ presented development failure, four $(5.40 \%)$ during the larvae stage and one $(1.35 \%)$ during the pupae stage. Parasitism was observed in 17 cells $(22.95 \%)$, of which three $(4.05 \%)$ were attacked by Sarcophagidae, three $(4.05 \%$ by Bombyliidae, three $(4.05 \%)$ by Chrysididae, four $(5.40 \%)$ by Ichneumonidae and four $(5.40 \%)$ by non identified parasites. Dead adults, that were not able to break through the closure plug, were found in five cells $(6.75 \%)$.

\subsubsection{Pachodynerus sp.}

Mortality was observed in $46(54.12 \%)$ of 85 provisioned cells. In 23 of these $(27.06 \%)$ there was development failure, of which twelve $(14.12 \%)$ in larvae stage, and eleven $(12.94 \%)$ in pupae stage. Parasitism was observed in 17 cells $(20.00 \%)$, of which six $(7.06 \%)$ were attacked by Sarcophagidae, five $(5.88 \%)$ by Bombyliidae, two $(2.35 \%)$ by Chrysididae, one $(1.18 \%)$ by Eulophidae and three $(3.53 \%)$ by non identified parasites. Dead adults that could not break through the closure plug were found in six cells.

\subsubsection{Pachodynerus argentinus}

Mortality was observed in two (40\%) out of five provisioned cells, due to development failure in the larvae stage. No parasitism was observed in this species.

\subsubsection{Pachodynerus ca guadulpensis}

No mortality was recorded in nests of this species.

\subsubsection{Pachodynerus nasidens}

Mortality was observed in eleven $(55 \%)$ out of 20 provisioned cells. In five of these $(25 \%)$ there was development failure during larvae stage and in two (10\%) during pupae stage. Parasitism by Chrysididae was observed in three cells $(15 \%)$. One dead adult was found in one cell $(5 \%)$. 


\section{Discussion}

Results obtained in this study show that despite the fact that most species of Pachodynerus are not very abundant, the richness of this wasp guild in the Parque Municipal das Araucarias is relatively high when compared to results obtained by other studies. Hermes and Köhler (2004), in the Santa Cruz green belt in Rio Grande do Sul, sampled four species of Pachodynerus, three of which were also sampled in our study. As for these authors, we also observed that $P$. guadulpensis is a relatively abundant species while $P$. nasidensis has an intermediate abundance and $P$. argentinus is rare. Camillo et al. (1995) and Assis and Camillo (1997), in their inventories in southeastern Brazil, sampled other species of Pachodynerus, of which only P. nasidens was also sampled in our study. In a two year inventory carried out in St. Catherine, Jamaica, Jayasingh and Freeman (1980a) sampled only Pachodynerus jamaicensis Bequard and Salt and $P$. nasidens nests, the latter considered domestic due to its high abundance in urban areas. In other studies carried out in Mexico by Carpenter (1986) and in Tamaulipas and Nuevo Leon by Cancino et al. (1993), Pachodynerus californicus Saussure, P. nasidens, Pachodynerus praecox Saussure and Pachodynerus acuticarinatus Cameron nests were sampled.

In relation to the habitats, the grassland areas showed a greater richness and a higher abundance of nests than the wetlands. Contrasting with that recorded by Freeman and Jayasingh (1975a, 1975b) in several Jamaican regions, in our studied areas $P$. nasidens nested only in open areas. In Jamaica, this species nested in partially or completely shadowed habitats. It is possible that this difference is due to the fact that the temperature in open areas in Jamaica is higher than those in Brazil, where in the hottest months it reaches a maximum $35^{\circ} \mathrm{C}$ (Buschini and Wolff, 2006). According to Jayasing and Taffe (1982), the ideal temperature for the development of the eggs of $P$. nasidens varies from 26 to $31{ }^{\circ} \mathrm{C}$, suggesting that Pachodynerus nests are absent from areas where the temperature is lower than $26^{\circ} \mathrm{C}$. Since all Pachodynerus species that occur in the Parque Municipal das Araucarias founded their nests in open areas, it is possible that the temperature affects the egg development of all species, and that this is one of the environmental factors that most influences the reproductive activities. This is confirmed by the fact that these activities were recorded, for all species, during the hottest months of the year.

In relation to nest architecture, there seems to be uniformity among the different species, as recorded by other authors (Jayasingh and Taffe, 1982; Assis and Camillo, 1997). In all of them, a layer of mud is normally deposited at the bottom of the nest and the cells are covered by a thin layer of mud. The cell partitions are smooth and concave externally and smooth and convex internally. The vestibular cells are present in most nests and intercalar cells built occasionally.

Another similarity among the species is the diameter of the trap nests. All of them used only those with a $0.7 \mathrm{~cm}$ diameter. In addition, at the beginning of the construction of the nest they build a mud closure plug at the entrance, with a central opening of smaller diameter than that of the trap nest. This hole remains open during and after the construction of the nest. Jayasingh and Taffe (1982), observed that the entrance orifice of $P$. nasidens nests initially presented a diameter wider than $0.5 \mathrm{~cm}$, but later the wasps built a temporary mud contour, reducing the diameter to 0.3 or $0.4 \mathrm{~cm}$, corresponding to the width of the species thorax. These authors suggested that this could be a way to diminish the competition for nesting sites with Trypoxylon texense Saussure, a slightly larger wasp than P. nasidens. By diminishing the diameter of the entrance orifice, $T$. texense would no longer be able to enter the nest. It is also possible that this occurs with the Pachodynerus species from the Parque Municipal das Araucarias, and that they are able to diminish the competition, especially with Trypoxylon lactitarse Saussure, a slightly larger wasp than Pachodynerus that also occurs in open grassland areas and wetlands, at the same time of the year and that uses $0.7 \mathrm{~cm}$ orifices. We also believe that the presence of this structure at the entrance of the nests of Pachodynerus species "informs" other species of bees and wasps, with smaller bodies, that site is already being used, thus diminishing competition. This would be the case of Trypoxylon opacum Brèthes, one of the most abundant wasp species in these environments and that uses exclusively $0.7 \mathrm{~cm}$ orifices. Krombein (1967) also considered that the diameter of the trap nests or cavities is probably determined by the size of the wasp's body or by competition with other species.

Jayasingh (1980) proposed a very important hypothesis for Eumenid wasps, especially $P$. nasidens. According the author, the provisioning of more or less food is determined by the variation in the time available for storing. This in turn, is caused by the slower or more rapid development respectively of female or male eggs. Normally, female eggs were longer than male eggs and mature slowly. Since the wasp normally continued to store a cell until the next egg was ready to be laid, the time difference between the maturation of a female and a male egg would affect the provisioning period for the two sexes. Thus the longer period of maturation of a female egg would necessitate a longer provisioning period for that cell which immediately preceded it, and consequently, that cell would get more food. The shorter maturation period of a male egg would reduce the provisioning time available for the cell prior to it, and consequently that cell would get less food. Considering the result of our study, this hypothesis does not adjust to any of the collected Pachodynerus species, since in all of them we observed a slight variation in the arrangement of the sexes within the nest. From one Pachodynerus nest and from $P$. nasidens nests males emerged from the innermost cells and were lighter than the females. In other nests of these species the sexes were intercalated, which also occurred in $P$. ca guadulpensis nests. Considering the female's weight, this hypothesis also doesn't adjust to our data, since not always did females emerge from 
the innermost cells and were heavier. Normally this did not occur. For Jayasingh (1980), this hypothesis seems to explain most of the anomalies pointed out earlier and also gives a logical explanation of how aculeate differentially invest in male and female progeny. It is possible that in this subfamily this is much more complex and requires further investigation because maybe this pattern can vary according to environmental conditions of the regions where the species occur. Thus, in Eumeninae the development of the subsequent egg might not be determined by the provisioning time of the egg laid before it.

Jayasingh and Taffe (1982) suggested that the sex ratio of $P$. nasidens could be influenced by the length of the internal orifice of the nests. This is due to the fact that short trap nests, of approximately $6 \mathrm{~cm}$, could have only 2 or 3 cells. Thus, the sex ratio would tend towards females, since the fertilised eggs would be those oviposited first. In our study we used $8 \mathrm{~cm}$ trap nests and for $P$. nasidens observed an average of 2.8 provisioned cells per nest. The sex ratio tended towards males, because the non fertilised eggs were usually those oviposited first. For $P$. guadulpensis that had more provisioned cells (3.5) per nest than $P$. nasidens, the sex ratio also tended towards males and male and female eggs were randomly deposited in the nest even though females emerged before males. Pachodynerus sp., a species with an average of 5.5 provisioned cells per nest, was the only one for which the sex ratio tended towards females and for which the eggs were also randomly deposited. Females of this species also emerged before males.

Generally, the greatest cause of mortality in Pachodynerus nests was development failure, even though parasites, such as Sarcophagidae, Bombyliidae, Chrysididae, Ichneumonidae and Eulophidae (Melittobia), were present. Rocha (1981) also observed that development failure was the main cause of mortality in P. nasidens, but that fungi and Amobia sp. were also responsible for some deaths. Jayasingh and Freeman (1975a), on the other hand, observed that Melittobia was the most important predator for $P$. nasidens. The mortality rate of P.nasidens in our study was higher $(55,0 \%)$ than that recorded in the study of these authors $(45,68 \%)$. According to Jayasingh and Freeman (1980b) strikingly in Jamaica, there were no Chrysididae, a family that commonly infests solitary wasps in other parts of the world. For them, it is probable that the small size and external method of feeding displayed by Melittobia as well as the fact that it can operate as a hyperparasites have eliminated most of its potential competitors for food in Jamaica, although both Melittobia and chrysidid wasps attack Aculeate in the U.S.A (Krombein, 1967) and in Trinidad (Taffe, 1979).

With these results we were able to conclude that, even though Pachodynerus species present common characteristics, such as nest architecture, nesting activities and habitats in which they occur, the used resources, mortality rates, etc., vary among groups of species occurring in different regions, and that the degree of variation of these characteristics is higher between individuals of the same species occurring in different regions than between individuals of different species occurring in the same region. Thus, detailed studies of their life histories will be able to give us relevant information on their ecological niches, enabling us to comprehend how they respond to different environmental factors. Parallel to these studies, investigations on their genetic material will allow us to describe their evolutionary history and evaluate if a greater genetic variability is present in species that occur in more heterogeneous environments and if this would explain the biological differences observed between this study and those of other authors.

Acknowledgments - Partial financial support was provided by the Fundação Araucária (The State of Paraná Research Foundation) and UNICENTRO (Guarapuava, PR, Brazil). We thank Prof. Bolivar R. Garcete-Barrett for wasp identification.

\section{References}

ASSIS, JMF. and CAMILLO, E., 1997. Diversidade, sazonalidade e aspectos biológicos de vespas solitárias (Hymenoptera: Sphecidae: Vespidae) em ninhos armadilhas na região de Ituiutaba. Anais da Sociedade Entomológica do Brasil, vol. 26, no. 2, p. 335-347.

BUSCHINI, MLT. and WOLFF, LL., 2006. Notes on the biology of Trypoxylon (trypargilum) opacum Brèthes (Hymenoptera; Crabronidae) in southern Brazil. Brazilian Journal of Biology, vol. 66 , no. 3, p. $915-926$

CAMILLO, E., GAROFALO, CA., SERRANO, JC. and MUCCILLO, G., 1995. Diversidade e abundância sazonal de abelhas e vespas solitárias em ninhos armadilhas (Hymenoptera: Apocrita: Aculeata). Revista Brasileira de Entomologia, vol. 39, no. 4, p. 459-470.

CANCINO, ER., TEJADA, LO., SÓSTENES, E. and VARELA, F., 1993. Eumeninae (Hymenoptera: Vespidae) em Tamaulipas y Nuevo Leon, Mexico. Folia Entomologica Mexicana, vol. 88, no. 1 , p. $79-88$

CARPENTER, JM., 1981. The phylogenetic relationships and natural classification of the Vespoidea (Hymenoptera). Systematic Entomology, vol. 7, p. 11-38.

CARPENTER, JM., 1986. The genus Pachodynerus in North America (Hymenoptera: Vespidae: Eumeninae). Proceedings of the Entomological Societyof Washington, vol. 88, no. 3, p. 3572-577.

CARPENTER, JM. and RASNITSYN, AP., 1990. Mesozoic Vespidae. Psyche, vol. 97, no. 1-2, p. 1-20.

CARPENTER, JM. and MARQUES, OM., 2001. Contribuição ao Estudo dos Vespídeos do Brasil. Bahia: Universidade Federal da Bahia. Série de Publicação Digital Universidade Federal da Bahia 3. CD-ROM.

CARPENTER, JM. and GARCETE-BARRET, BR., 2002. A key to the Neotropical genus of Eumeninae (Hymenoptera: Vespidae). Boletin del Museo Nacional de Historia Natural del Paraguay, vol. 14, no. 1-2, p. 52-73.

COWAN, DP. The solitary and presocial Vespidae. In ROSS, KG. and MATTHEWS, RW. The Social Biology of Wasps. New York: Cornell University Press, 1991. p. 33-73.

FREEMAN, BE. and JAYASINGH, DB., 1975a. Population dynamics of Pachodynerus nasidens (Latr.) in Jamaica (Hymenoptera: Eumenidae). Oikos, vol. 26, no. 1, p. 86-91. 
FREEMAN, BE. and JAYASINGH, DB., 1975b. Factors controlling the distribution in Jamaica of Pachodynerus nasidens (Latr.) (Hymenoptera; Eumenidae). Biological Journal of the Linnean Society, vol. 7, no. 3, p. 231-241.

HERMES, MG. and KÖHLER, A., 2004. Chave ilustrada para as espécies de Vespidae (INSECTA, Hymenoptera) ocorrentes no cinturão verde de Santa Cruz do Sul, RS, Brasil. Caderno de Pesquisa série Santa Cruz do Sul, vol. 16, no. 2, p. 65-115.

JAYASINGH, DB., 1980. A new hypothesis on cell provisioning in solitary wasps. Biological Journal of the Linnean Society, vol. 13 , no. 2, p. 167-170.

JAYASINGH, DB. and FREEMAN, BE., 1980a. Trap-nesting solitary aculeates (Insecta: Hymenoptera) in St. Catherine Jamaica. Caribbean Journal of Science, vol. 15, no. 3-4, p. 69-78.

JAYASINGH, DB. and FREEMAN, BE., 1980b. The comparative populations dynamics of eight solitary bees and wasps (Aculeata:
Apocrita: Hymenoptera) trap-nested in Jamaica. Biotropica, vol. 12 , no. 3, p. 214-219.

JAYASINGH, DB. and TAFFE, CA., 1982. The biology of the eumenid mud-wasp Pachodynerus nasidens in trap-nests. Ecological Entomology, vol. 7, no. 3, p. 283-289.

KROMBEIN, KV., 1967. Trap nesting wasps and bees: life histories, nests and associates. Washington: Smithsonian Inst. Press.

ROCHA, IRD., 1981. Biologia e ecologia da vespa solitária Zeta argillacea (Hymenoptera, Eumenidae). Ciência e Cultura, vol. 33 , no. 1 , p. 87-92.

TAFFE, CA., 1979. The ecology of two West Indian species of mud-waps (Eumenidae: Hymenoptera). Biological Journal of the Linnean Society, vol. 11, no. 1, p. 1-17.

WILLINK, A. and ROIG-ALSINA, A., 1998. Revision del gênero Pachodynerus Saussure (Hymenoptera: Vespidae, Eumeninae). Contributions of the American Entomological Institute, vol. 30, no. 5 , p. 1-117. 
